\title{
the industrial versus the artisanal
}

\author{
By Rod Stoneman
}

Spring 2000 Issue of KINEMA

\section{UNDER THE SHADOW OF HOLLYWOOD: THE INDUSTRIAL VERSUS THE ARTI- SANAL}

IN 1848 a certain manifesto began with the words: 'A spectre is haunting Europe...' Now, almost 150 years after that seminal pamphlet was written and in the post-industrial epoch, the sentence could well continue with the words ' -- the spectre of Hollywood.'

A range of statistics indicate the urgency and seriousness of the situation: American films have gained more than a $90 \%$ share of the Irish and British markets in recent years and the proportion is similarly unbalanced in most other countries of the world. ${ }^{(1)}$ The figures are stark correlatives of debilitated production sectors and weakened reception structures -- European cinema as a whole may be in a period of remission...

Given the scale of the incursion that has already taken place, the belligerent discourses and robust negotiation of the American industry in relation to the 1994 GATT round may seem initially disconcerting. But their antagonism was less aimed at capturing the last meagre percentages of the theatrical market that is still available in most countries than attacking what, from the American point of view, is a much more serious barrier -- the European Union's 'Television Without Frontiers' directive -- which stipulates that over 50\% of all transmitted programmes must be of European origin where possible. At the moment the average percentage of American product shown on European television is $35 \%$.

The belated European response, in pointing to the dangers of an American victory at the GATT negotiations, rallied French actors and German directors and at last brought previously invisible economic and cultural shifts abruptly into the light of public debate... Their significance and long term implications could hardly be understated. The defence of their notional national culture is one topic that opposite ends of the political spectrum can agree on, albeit for different reasons.

Generalised denunciations and cries of 'cultural imperialism' echoed the angry slogans of '68, a year which radicalised a generation and spread the third world critique of American power to significant sections of the West. ${ }^{(2)}$ But, over twenty-five years later, contemporary anger at the domination of American cinema can easily degenerate into the manichean denunciation and rejection of American culture as 'crass, sick, retarded, despicable...' in John McGrath's polemical formulation. ${ }^{(3)}$

Such understandably furious, reductionist responses, like other simplistic formulations of the relationship between economy, ideology and representation, are often predicated on intention: '[Hollywood] sneaks into every shot the world-view of the most cretinous, vile sections of the American people ... the most deeply insane nation of the world including North Korea; on the surface bluff, straight talking but with a profundity of hypocrisy and Bad Faith at its core that is close to psychotic..(4)

But intention is often a self-deluding projection and nearly always beside the point. Films function in different ways in different contexts and their texts can also be read against the grain. Hollywood, like other concerted representational regimes that have evolved over long historical periods, is not monolithic -- its perennial strength has been precisely its ability to ingest, assimilate and incorporate. This is evident both literally in the five generations of European film-makers, writers and actors who have relocated to California ${ }^{(5)}$ and in the more complex intertextual and reciprocal play of influences between European and American cinema that has existed since its origins.

It is more productive to look for signs of movement and political contention within American culture and society if we are to avoid generalised condemnation and dismissal of Hollywood as 'a bad thing', somehow intentionally wicked and malevolent. We should also acknowledge and understand our own pleasures born of its machinery and the meanings that machinery produces. Hollywood's power and accomplishment is partially a result of the strength and precision of its narrative effects. There are many reasons to resist loose dismissals of American cinema, or indeed American culture overall, rather to concentrate on developing a focused critique against the global hegemony, the domination of that culture. 
This article will attempt to delineate some aspects of the industrial mode of production that characterises American cinema. It is distinct from other methods of production in the rest of the world; although there is a distant echo of its approach in particular third world variants such as the film-making that emanates from Bombay, Hong Kong, Cairo. They are also 'industrial' approaches to some extent -- but they are culturally and economically limited and totally lack export power.

Quite apart from scale, film production practices outside Hollywood are characterised by significant differences at every level -- perhaps they can be usefully described as artisanal in contrast to the industrial model. These are not just semantic distinctions-- radically different approaches to production are at stake.

\section{the same}

There is a paradox at the centre of cultural phenomenon: each one is different, but the same. Hollywood exploits recapitulation to the full in the wish to repeat, to utilise formulas to predict and to maximise commercial returns. Standardisation happens in different ways and at different levels of an industry which has always made most of its cinema within broad generic conventions. The films and their marketing work to establish wide areas of generic narrative recognition like the Western, the middle class romantic comedy, the social realist drama, the science fiction film etc.

A heightened version of the formulaic impulse can be seen in the overt development and marketing of sequels and follow-ons. Occasionally the desire for the sequel even invades the end of the previous film as with the quirky, 'trailer' endings of Back to the Future or Silence of the Lambs. Perhaps the repetitive imperative is at its most literal in Hollywood's remakes of films from elsewhere -- Nikita, Diva, Three Men and a Cradle.

Hollywood exhibits what, in a psycho-analytical context, might be described as repetition compulsion. ${ }^{(6)}$ This tendency towards replication reinforces its marketing strategies. When someone pays for a $£ 5$ ticket to see a Hollywood film, that spectator implicitly 'knows' what he or she will receive, what will be experienced in the two hours spent in the cinema. This precise and reliable structure for exchange value is often in contrast to the less specific expectation and much less predictable outcome associated with attending films made by other cinemas from different parts of the world. If you go to an American film there is a sense that it will operate and deliver its narrative pleasures within a narrow band of expectations. But if you go to a new Swedish or English or African (or indeed American independent) film you must be prepared for the marvellous or the dreadful, and everything in between.

There is some equivalence in beverage production and marketing: Coca Cola, that quintessentially American drink, is a standardised product with a franchised production structure, the same can of Coke is available in Boston or Berlin, Bogota or Belfast, it is indeed the 'real thing' and Pepsi, its nearest and undifferentiable rival, is also American owned. In contrast, diversity is part of the pleasure available in any encounter with European wine or Scottish whisky -- the range and variation of the field offers a more fascinating but much less reliable experience. There is some sense that the exploration of diversity has its own risks, but also its own pleasures.

\section{highly hierarchical}

American film production is extremely hierarchical, there are vigorous divisions of rank and power in all aspects of its organisation. Producers', studios', managers' and agents' power is articulated within specifically defined territories, their fields of contention are allowed within controlled parameters. Every studio production works its way through rigidly defined command structures. There is an acute degree of separation and division of labour to achieve this end. The highly paid and highly alienated labour is often categorised and reduced to easily replaceable permutations -- a large number of scriptwriters and 'script doctors' can be deployed on any one project. In a less auteurial system directors are also dispensable and substitutions can be made during actual production. All this works to strengthen the powerful narrative machinery -- the number of drafts, early input from distributors, use of test screenings. There is often contention around casting; the much lauded system of stars is less about 'acting' than image control and marketing.

\section{trade}

Whilst Hollywood cinema is clearly and coherently commercial in its intent, manufacture and marketing, there is always some interaction between 'commerce' and 'culture' in all audio-visual production (precisely the cultural industries). We must not fall into a facile Art / Commerce distinction here. ${ }^{(7)}$ There is a 
specific invocation of the audience at an early stage of industrial production, input from those involved in marketing and distribution is easily facilitated in vertically integrated companies. Thus the later stages of the distribution and exhibition processes are integrally involved in pre-production decisions. When a film has been shot and edited the use of test screenings gives a further indication of audiences' reactions to the hypothetical text. It is this constant attention to and anticipation of the audience that increases the predictability of the reception and commercial potential of American cinema. Even so the complex combination of factors that determine success in a 'cultural' industry means that many American films will not make a profit.

American companies are unashamedly monopolistic, taking gradual control of most aspects of the international film distribution business. They are implacably and uninhibitedly commercial in all aspects of their approach, from the initial script or concept (revealingly called a 'property') to the long term control of rights. The usual disingenuous deployment of that old discursive slippage: free market equals free will, works well. In the new communicative order democracy is equated with the expression of choice of what to consume.

A century after its initiation the American version of cinema has an absolutely confident self-image, accompanied by little or no self-consciousness or self-awareness whatsoever; as enunciated by Whoopi Goldberg introducing a recent Oscar ceremony as "the best of Hollywood cinema, which is the best of world cinema..."

\section{a question of scale}

The large critical mass of American production leads to important economies of scale all the way through the production, distribution and exhibition processes. The advantages of scale and amalgamation lead to the felt power achieved by the integrated marketing and distribution of American film ${ }^{(8)}$. At its best, the co-ordinated release of a new film is timed to make maximum impact in different territories ${ }^{(9)}$ at the same time. It combines both local expertise, for necessary variation, and overall control to achieve the maximum profile for a new release. When it all works very considerable profits can be made quickly -- the world wide figures of a successful American movie are bigger than the annual budget of Rwanda and Zaire and Burundi put together.

\section{artisanal cinema}

Production approaches outside Hollywood tend to provide a degree of contrast in each of these areas: instead of a reliance on repetition there is a desire for diversity. A tendency to accentuate the highest degree of difference through the stress on the auteur (generally the director, but occasionally the writer or producer) accentuates the idea of each film expressing an individual's vision. This desire for differentiation is manifest within European cinema as a whole and also within specific national cinemas: Italian cinema is broadly different from, say, Swedish cinema and particular cultures are fascinated by the degrees of difference manifested by individual directors within their distinct national cinemas.

This desire can also be seen at work in the French critical reading of Hollywood in the fifties and sixties. The formulation of a politique des auteurs by Cahiers du cinéma can be seen as a 'European' intervention, re-reading industrially produced American cinema to find the specificities which enable critical discourses, based on the idea of the individual subject as the punctual source of creation, to emerge and eventually dominate internationally.

Hitchcock was one of very few directors who had something of an established 'brand name' from an early stage but pre-war popular audiences largely did not 'read' the director's credit, perceiving and choosing films by star and genre. Now, however, even formulaic blockbusters must be labelled with an 'author' (or associated with one as when Spielberg or Lucas are acting as executive producer). The moment of critical elaboration which concentrated on the mise-en-scene and the weltanschauung of John Ford and Howard Hawks, later Jacques Tourneur and Nicholas Ray, was not just a retrospective or historical exercise. It initiated a significant change in the way that new films were publicised and promoted. Ironically this European intervention had an effect on Hollywood self-definition and, arguably, practice. It was also taken up by American critics and journalists and carried to alliterative excess in Sarris' book The American Cinema. ${ }^{(10)}$

European state funding agencies (let alone the peculiar versions of state controlled studio systems constructed in Eastern European socialist countries up to the end of the eighties) have always been more cultural than commercial in approach and method. From the nineties an economic emphasis has been added to the national 
and cultural aims of many of the agencies. As a result of historical and political shifts these more mixed motives are now apparent in the discourses which support many state subventions. But it is important that a judicious equilibrium between the cultural and the economic is maintained -- the worrying example of consistently weak product emanating from the relatively prosperous German regional funds indicates that high levels of subsidy alone do not lead to a thriving cinema culture.

At its best European cinema can draw upon a particular cultural fertility; there is a depth of history and richness that comes from generations of imagination coming to terms with a particular place and set of circumstances. ${ }^{(11)}$ This strength is based on the specific effects of a network of a myriad of smaller scale independent production operations thrown erratically across the continent. Attempts to conglomerate the production structures within large scale euro-studios are destined for calamity.

It will be necessary to throw out the fantasy, buried in unconscious expectations (especially those of English language cinema), of competing with and ultimately beating Hollywood on its own ground. The notion of replicating large scale state industries, with the same power and reach as the American is a chimera and delusion. ${ }^{(12)}$ Whatever the lustrous histories of the various European national cinemas their futures do not lie in large scale production. There is no, and there will not be, an Irish, Italian, British film 'industry' in the American sense.

\section{strategies}

Appropriately enough, the first version of these thoughts on ways in which smaller scale national cinemas could survive and even surpass the economic assault of Hollywood production was prepared for a seminar with Vietnamese film-makers in Hanoi. ${ }^{(13)}$ The central principle of guerilla warfare, pioneered by Irish fighters in the early years of this century, is to play to one's own strengths, to acknowledge the imbalance of the enemy's size and power and turn it to advantage of the insurgent. A cultural analogy with such guerilla tactics needed little explanation in Vietnam -- the lived experience of a small, poorly equipped peasant militia successfully taking on the most well-armed, technologically advanced super-power is still vivid.

At the time of the Hanoi discussion The Scent of Green Papaya (Tran Anh Hung, 1993) was nominated for the foreign language category of the Oscars. This film can be seen as a particularly interesting example of the hybrid nature of artisanal production. French financed, it was shot in a Paris studio with a French crew; set in Saigon in the thirties, it articulates an authentic Vietnamese vision of that moment in history and cultural transition ...

Perhaps the financing and making of this particular film also provides an example of the possibility of strategic alliances between various artisanal cinemas to their mutual benefit. Different countries can work together in different configurations to create a broad range of modestly budgeted film. As long as they respect, and indeed intensify, their cultural specificity...

In addition to the cultural and political logic for this strategy there are pertinent commercial motives to support the production of a larger number and wider range of lower budget films. When such films are successful they are able to make profits for producers and investors much faster. Crying Game has better 'gearing' (the ratio of production cost to exhibition return) than Jurassic Park. There was a unique moment in Hollywood provoked by Easy Rider in 1969. The world-wide success of Dennis Hopper's small budget road movie convinced studios to switch policy to the idea of supporting twenty low budget films with a clear anticipation that, although nineteen would lose money, the twentieth would do well enough to pay for the others and generate substantial profits. Even though it was not consciously devised or adopted in terms of pluralism, this approach gave greater space and room for diversity. It was relatively short lived, as the eighties saw the studios return to higher investment in a smaller number of films. Commercial policies shift, and will change again. American large budget cinema is over-extended, its hegemony is vulnerable and will become defensive.

Other cultural forms (literature, the visual arts) indicate the way in which pluralism can function productively -- a vigorous and constructive interaction between films and the approaches to cinema they represent. It is diverse artistic forms arguing with one another through their publics that leads to the sustainable development of creative cultures...

We must take steps -- logical, careful, bold steps to encourage the growth of the native film cultures of 
Europe, Africa, Latin America and Asia. To enhance radical pluralism within and between each site, to build alliances, play to our cultural strengths, accept and celebrate the scale and difference of the world's cultural production. In film-maker Derek Jarman's words : "Consider the world's diversity and worship it." (14)

\section{Notes}

1. The degree of penetration depending on the year and the country in question; the only exceptions to the general range of the 55-95\% ingression of American product are India (as a result of the rich specificity of its indigenous product), closed countries like Iran and the effect of strict protectionism in territories like South Korea.

2. From 'Yankees go home' in the Dominican Republic in the Fifties, to Vietnam in the Sixties and Seventies and the 'Great Satan' of the Iranian revolution in the Eighties.

3. John Mc Grath, 'Sex, Violence and the Cultural Imperative', The 1994 Celebrity Lecture at the Edinburgh Film Festival.

4. McGrath, op.cit., page 4.

5. Murnau and Ingram, Lang and Sternberg, Wilder and Hitchcock, Scott and Verhoven.

6. See also 'The Future of an Illusion', Film Ireland, December, 1994.

7. At some conference in Washington in 1996 I met an American diplomat who had been involved in the GATT negotiations; talking of commerce/culture she immediately recognised this as "oh yes the Cola/Zola debate"-- a characteristically succinct and marketable version of the binary opposition.

8. David Puttnam, The Undeclared War, 1997.

9. These territories are probably best conceived within linguistic parameters in the era of satellite footprints and on-line communications that do not recognise national or geographical boundaries.

10. Andrew Sarris, The American Cinema. Directors and Directions 1929-1968, 1968.

11. Cf John McGrath, op. Cit., page 5. 12. A mirage that is already making an appearance in the EU policy documents emanating from MEDIA II.

13. Different versions of this paper were initiated in 1994, evolving through presentation and discussion at: Vietnam Cinema, Hanoi in February; at the Filmbase AGM in Dublin, 27 March (report published as 'Not the Irish Film Industry', Film Ireland, April/May 1994; at the Celtic Film and Television Festival, Derry in March; and at the Carthage Film Festival, as part of the colloquium 'Le cinema au sud face à l'exception culturelle', Tunis, 16 November.

14. Derek Jarman, Chroma, page 75.

\section{Author Information}

Rod STONEMAN is Director to Huston School of Film and Digital Media, National University of Ireland in Galway. He previously served as Chief Executive of the Irish Film Board and a deputy commissioning editor of independent film and video at Channel Four. He has made several independent programmes for television (including "Between Object and Image," "Ireland: The Silent Voices," and "Italy: The Image Business"), written for Screen, Sight and Sound, Framework, and Afterimage. 